DARIUSZ JURUŚ 1

\title{
REVIEW: MICHAEL PATRICK LYNCH, TRUE TO LIFE: WHY TRUTH MATTERS. TRANS. D. MISZTAL, LODZ UNIVERSITY PRESS, ŁóDŹ 2020, PP. 491.
}

The author was prompted to write this book by, as he puts it, his fear of the slide of Western democracies towards an attitude of post-truth (p. 12). Lynch, contrary to the currently common attitudes in the humanities and even partly in the sciences, defends objective truth. The central argument of Lynch's book is that truth is important and that it is necessary to understand all those errors that lead to the denial of the validity of truth. One such error is to confuse truth with certainty and to treat it as a metaphysical mystery. The simple example Lynch refers to shows that truth can exist independently of certainty. For we do not know whether the number of stars in the universe is even or odd. So here we have no certainty about objective truth (p. 17).

The motto of the introduction can be the following sentence: "If something is true, it does not mean that you will believe in it; and if you believe in something, it does not mean that it is true" (p. 17).

In the book, Lynch defends four theses: (i) truth is objective; (ii) it is good to believe what is true; (iii) truth is a valuable goal of inquiry; (iv) truth is worth worrying about for its own sake (p. 31). According to Lynch, the point of having an idea of truth is to be able to distinguish between correct and incorrect judgments (p. 415).

Lynch criticizes the views of opponents of objective truth in turn: that truth is not valid because it is not attainable, that it is relative, and that falsehood is often more useful than truth.

${ }^{1}$ Dr. hab. Prof. JU; Jagiellonian University in Kraków; ORCID: 0000-0002-2018-9361; dariusz.jurus@uj.edu.pl. 
To acknowledge the existence of objective truth, Lynch encourages us to recognize a simple truth: there are some things that we simply will never know and some things that we think we know, though it is otherwise (p. 39). Lynch maintains, in keeping with the classical definition of truth, that "true beliefs are those that paint the world as it is" (p. 45) Truth in Lynch's view is also good because it is better to believe something that is true than something that is false. Besides, truth is also a valuable goal of our pursuits. For it is good to pursue the truth. Truth, as Lynch writes, is worth worrying about for its own sake (p. 52). For it has a normative dimension. It is more like love than money (p. 56). Lynch convinces us that truth is not indifferent, that we would rather live with true than false beliefs, even in cases where both have the same instrumental value. Truth has both normative and non-normative value, according to Lynch. "When we describe an act as courageous," Lynch writes, "then we are both describing and valuing it" (p. 64). The same is true of truth; when we say that something is true, we are not just stating a fact, we are valuing that belief.

However, Lynch warns us against beliefs that harm truth and give weapons to its critics. These include such claims as: there is only One Truth, only "pure" reason has access to the truth, the truth is mysterious, only certain people can know the truth, and we should pursue the truth at all costs (p. 65).

In spite of critics (Rorty, Davidson) who claim that truth as unattainable cannot be the goal of human pursuit, Lynch argues that truth, though not easy, is nevertheless attainable. Lynch rejects the thesis that the truth of a belief is verified by contact with facts "in themselves." "We identify," Lynch writes, "what is true and what is false indirectly by recognizing, as one might put it, signs of truth and falsity-that is, by recognizing what is justified and what is not" (p. 81). Thus, one can know that something is true without being certain that this belief is correct. On the other hand, man seeks certainty, which gives him a sense of security. Therefore, he seeks truth. However, Lynch warns against those who think they have possessed absolute truth. For this is dogmatism, which leads, in contrast to objectivity, to intolerance. For Lynch emphasizes that objectivism about truth leads to tolerance. "If truth is objective," Lynch states, "then we must always be open to the possibility of being wrong" (p. 98).

In addition to its epistemic dimension, truth also has a normative dimension, for, as Lynch writes, "being true is what makes a claim good to believe" (p. 156). 
Lynch criticizes both the pragmatic and coherence definitions of truth. The former is unable to explain what makes beliefs pragmatically justified, while the latter cannot deal with the question of what determines the truthfulness of the fact that one system is coherent and another, not. (p. 177, 186). Lynch also indicts the version of pragmatism (neo-pragmatism) represented by R. Rorty and argues, criticizing Rorty, that justified beliefs and true beliefs are not the same thing, and that truth is not contextual, i.e., relative to a given community (pp. 187-197).

Lynch also criticizes naturalism in its reductionist form, maintaining that truth cannot be reduced to some physical property. For if this were the case, truth would cease to be a value to be pursued (p. 204). Lynch also rejects the verificationism that underlies naturalism, holding that "verifiability is not necessary for truth in general" (p. 214). For we are unable to verify, for example, the following statements: "On the same day as today, but 15,000 years ago, it rained in this place," or "At this moment there are an even number of stars in the universe" (p. 213). "Truth," Lynch writes, "cannot be reduced to verification because verification must be explained in terms of truth" (p. 216). The question arises: how does one verify the very claim that all claims must be verifiable?

Lynch, significantly, does not see truth only in its epistemic dimension. He links it to happiness. For he claims that having true beliefs - about what we care about - is also part of happiness (p. 333). He also adds that "the truth about what we care about is itself worthy of being cared about for its own sake" (p. 334). According to Lynch, one should care about truth because it is a constitutive good that includes honesty, authenticity, and selfrespect (p. 374). Truth is simply something important to living a good life.

Lynch argues that truth is important not only in private life but also in political life. Contrary to what Rorty says, Lynch argues that objective truth is central to liberal democracy (p. 413). At its core is respect for each individual. Liberalism also requires rights, the idea of which must be founded on the idea of objective truth. For what is at stake are not political rights but fundamental rights.

According to Lynch, objective truth is therefore important for epistemic, moral and political reasons. We simply cannot do without objective truth.

It is sad, however, that in defending truth today we must add the adjective "objective." In the time of Aristotle, Kant or Husserl this was not necessary. 